Acta Universitatis

Nicolai Copernici

Zabytkoznawstwo i Konserwatorstwo XIII, Torun 2011

\author{
Małgorzata Geron
}

Zakład Historii Sztuki Nowoczesnej UMK

\title{
Obrazy wielopłaszczyznowe Tytusa Czyżewskiego
}

$\mathrm{O}$

ryginalnymi pracami, świadczącymi o poszukiwaniu nowych środków wyrazu, powstałymi w kręgu Formistów, były obrazy wielopłaszczyznowe Tytusa Czyżewskiego ${ }^{1}$. Niestety wszystkie zaginęły bądź też uległy zniszczeniu. Jedyną ich dokumentację stanowią słabej jakości fotografie, co bardzo utrudnia przeprowadzenie analizy. $\mathrm{Na}$ obecnym etapie badań znanych jest sześć zdjęć obrazów wielopłaszczyznowych, choć spisy katalogowe wskazuja, że mogło być ich więcej.

Już na pierwszej wystawie Formistów w Krakowie w 1917 roku Czyżewski, obok siedemnastu olei, akwarel i pasteli, zaprezentował cztery obrazy wielopłaszczyznowe: Salome, Pejzaż z aeroplanem, Portret i Wnetrze $e^{2}$. Pierwszy z nich jest znany z fotografii oraz komentarza autorskiego za-

Problematyka obrazów wielopłaszczyznowych była wcześniej podejmowana głównie przez Joannę Pollakównę w następujących publikacjach: J. Pollakówna, Tytus Cayzewski - Formista, [w:] Z zagadnieńn plastyki polskiej w latach 1918-1939, pod red. J. Starzyńskiego, Wrocław-Warszawa-Kraków 1963; eadem, Tytus Czyżewski, Warszawa 1971; eadem, Formiści, Wrocław-Warszawa-Kraków-Gdańsk 1972.

2 Katalog 1. Wystawy Ekspresjonistów Polskich, Towarzystwo Przyjaciół Sztuk Pięknych, Kraków, listopad-grudzień 1917, proj. okładki J. Hrynkowski, poz. 62-65. 
mieszczonego w czasopiśmie „Wianki”, natomiast Portret (Glowa) ilustruje recenzję wystawy, opublikowaną na łamach „Nowości Ilustrowanych”4. W 1919 roku obrazy wielopłaszczyznowe zostały pokazane dwukrotnie na wystawach grupy w Warszawie i Krakowie. Ze spisu zawartego w katalogu pierwszej prezentacji Formistów w stolicy wynika, że przedstawiono na niej trzy obrazy wielopłaszczyznowe znane jedynie z tytułów: Dom, Aeroplan i Krajobraz.5. Z kolei na drugiej z wystaw odbywających się w 1919 roku artysta pokazał Glowe i Kompozycje $e^{6}$. Można je zobaczyć na niewielkiego formatu fotografii w „Nowościach Ilustrowanych”, stanowiącej fragment ekspozycji dzieł Czyżewskiego, nazywanego „indywidualnością szukająca formy nowej"' " W 1921 roku na czwartej wystawie Formistów w Krakowie malarz zaprezentował kolejne cztery obrazy wielopłaszczyznowe: Kompozycja form I, Komposycja form II, Krajobraz ze stońcem i Gtowa, które kilka miesięcy później zostały przedstawione na następnej wystawie grupy w Warszawie ${ }^{8}$. Zdjęcie jednej z Komposycii form, określonej także jako Komposycja wieloplaszcyyznowa, dołączono do materiału ilustracyjnego zawartego w publikacji Formiści polscy Konrada Winklera'. Reprodukowana kilka lat wcześniej jako Komposycja form. Obraz wieloplaszcryznowy, datowana na 1918 rok, pojawiła

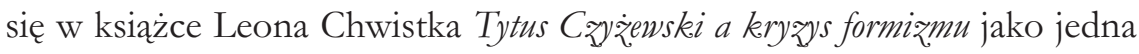
z trzynastu reprodukcji prac Czyżewskiego obok wymienianych wyżej: Sa-

3 T. Czyżewski, „Salome”. (Obraz wielopłaszczyznowy), „Wianki”, 1919, nr 1, s. 17, fot. s. 19; Formisci, pod red. I. Jakimowicz, Muzeum Narodowe w Warszawie, Warszawa 1989, poz. 160 , s. 44.

4 [b.a.], Wystawa „ekspresjonistów” polskich, „Nowości Ilustrowane”, 1917, nr 48 (1 XII), s. 7-8; Formiści, poz. 166, s. 44.

5 Katalog I Wystawy Formistów Polskich poprzedzony wstępem objaśniajacym, Polski Klub Artystyczny Hotel Polonia, Warszawa 1919, poz. 9-11. Prawdopodobnie praca znana tylko z tytułu - Aeroplan - mogła odpowiadać Pejzażowi z aeroplanem, przedstawionemu na pierwszej wystawie grupy w $1917 \mathrm{r}$.

6 Formiści Wystawa III. Katalog, Towarzystwo Przyjaciół Sztuk Pięknych, Kraków 1919, poz. 25-26.

7 [b.a.], Wystawa Formistów, „Nowości Ilustrowane”, 1919, nr 39, s. 7.

8 Katalog Formiści. Wystawa IV, Kraków, styczeń-luty 1921, poz. 41-44; Katalog Formiści. Wystawa X, Warszawa, kwiecień-maj 1921, poz. 33-36.

9 K. Winkler, Formiści polscy (seria „Monografie Artystyczne”, t. 14), Warszawa 1927, il. nlb. 
lome. Obraz wieloplaszcryznowy (1915), Gtowa. Obraz wielopłaszcryznowy (1916), Krajobra: Obraz wieloplaszcsyznowy (1916) ${ }^{10}$. Druga Komposycje form, podpisana jedynie jako Obraz wieloplaszcryznowy, włączono do recenzji wystawy krakowskiej opublikowanej przez „Nowości Ilustrowane”" , a także pokazano jej reprodukcję opatrzona podpisem i data - Obraz wielopłaszcryznowy (1920) - w czasopiśmie „Formiści” z maja 1921 roku $^{12}$. Praca ta w 1933 roku została przekazana przez grupe „a.r.” do zbiorów Muzeum Sztuki w Lodzi, niestety zaginęła w czasie II wojny światowej. W zachowanej dokumentacji określono ja jako „Komposycja wieloptaszcryznowa, malowidło olejne, drzewo" o wymiarach $75 \times 55 \mathrm{~cm}$. Była ona eksponowana w Sali formizmu, o czym świadczy zachowane zdjęcie z 1938 roku, na którym widnieje obok innych dzieł Czyżewskiego (Klucz, wiolinowy, Hiszpania, Komposycja form, Obtoki, Ptaszek) i Piety Zbigniewa Pronaszki ${ }^{13}$.

Wymienione obrazy wielopłaszczyznowe wzbudziły duże zainteresowanie krytyki artystycznej, oceniającej je krańcowo różnie.

Stanisław Mróz, zwolennik formizmu sportretowany przez Czyżewskiego w 1918 roku $^{14}$, analizując twórczość krakowskich artystów w kontekście nowych nurtów w sztuce, w recenzji z pierwszej wystawy stwierdzał: „Z futuryzmem zaś łączy ekspresjonizm zarówno świadome i celowe zaniechanie perspektywy, jak też powodujące tamto pierwsze, dążenie do wyrażenia środkami malarskimi ruchu, a raczej, u ekspresjonistów, płynności wszelkich kształtów, jako istoty świata form (ciekawym niezawodnie w tym kierunku na wystawie eksperymentem są wielo-

10 L. Chwistek, Tytus Czyżenski a kryzys formizmu, Kraków 1922, il. nlb., przedruk: L. Chwistek, Wybór pism estetycznych, wprowadzenie, wyb. i oprac. T. Kostyrko, Kraków 2004, s. 111-114.

11 Zob. [b.a.], IV Wystawa formistów, „Nowości Ilustrowane”, 1921, nr 12, s. $10-11$.

12 T. Czyżewski, Obraz, wieloplasz̨zyznowy (1920), repr. „Formiści”, z. 5, 1921 (maj), s. 5.

13 Za informacje dotyczace niniejszego obrazu wielopłaszczyznowego autorka pracy składa podziękowania Pani Mirosławie Motuckiej, kierownik Działu Dokumentacji Naukowej Muzeum Sztuki w Lodzi.

14 Formiści, poz. 134, s. 43, il. 81. 
płaszczyznowe obrazy T. Czyżewskiego)"15. Także z futuryzmem wiązał prace Czyżewskiego anonimowy autor artykułu zamieszczonego w „Nowościach Ilustrowanych”: „w wielopłaszczyznowych obrazach - pomyśle oryginalnym - pewną wspólność z futuryzmem, przez dążenie do wyrażenia niestałości, płynności wszelkich kształtów, tej najistotniejszej właściwości świata form, która jest ruchem"16. Z kolei A. Prędski określił Czyżewskiego jako artystę, „który jeden z pierwszych u nas wprowadza eksperymenta malarstwa wielopłaszczyznowego"'17. Zgoła odmienną opinię wyraził Mieczysław Dąbrowski: „Obrazy wielopłaszczyznowe są zaprzeczeniem zdrowego i logicznego pojęcia o świecie rzeczywistym, który można rozkawałkować kubistyczno-futurystycznie jeszcze w dowcipniejsze rebusy i stworzyć jeszcze komiczniejszy absurd. Albowiem na głowie zawsze będzie nos i ucho - pięta lub łokieć nigdy. To już nie eksperyment, ale szarlataneria ultrafuturystyczna" ${ }^{\prime 18}$. Podobną postawę prezentował anonimowy recenzent „Przeglądu Powszechnego”: „obrazy wielopłaszczyznowe. Są one kwintesencja ekspresjonizmu; jakie nowe głupstwo po nich przyjdzie, na razie nie wiadomo. Proszę wyobrazić sobie malaturę, wykonaną na kilku stykających się ze sobą pod rozmaitymi kątami płaszczyznach, i to tak, że na jednej z nich widać coś, niby oko, na drugiej - coś, niby usta, na trzeciej - coś, niby podbródek, a wszystko to razem nazywa się Portretem" ${ }^{\prime 1}$. Niewiele różniącą się ocenę prac pokazanych na krakowskich wystawach Formistów w 1919 i 1921 roku przedstawili kolejni recenzenci, opisując je jako „wielopłaszczyznowe potworności”20, „skrzynki, w które powprawiał kawałki blachy i innych rupieci i wywiesił jako wielopłaszczyznowe obrazy estetycznie równoważne z bryłami,

\footnotetext{
15 St. M. [Mróz], Wystawa ekspresjonistów polskich, „Głos Narodu”, 1917, nr 282,

16 [b.a.], Wystawa „ekespresjonistów” polskich, s. 7.

17 Dr A. P. [Prędski], „Ekspresjoniści polscy”, „Gazeta Narodowa”, 1917, nr 363
} s. 2. (20 XII), s. 3.

18 M. Dąbrowski, Ekspresjonizm i ekspresjoniści polscy. Pierwsza nystawa ekspresjonistów polskich w Krakowie, cz. 2, „Ilustrowany Kurier Codzienny”, 1917, nr 350 (19 XII), s. 2.

19 (ka), Z wystawy Towarzystwa Sztuk Pieknych w Krakowie, „Przegląd Powszechny", 1917, R. 34, s. 634.

20 Wasz., List z. Krakowa, „Kurier Warszawski”, 1919, nr 260, s. 7. 
na których namalował dziecinny krajobraz ze słońcem lub jakąś twarz"21, albo: „Kubistyczne [...] próby wielopłaszczyznowych brył z namalowana dziecinnie twarzą lub pejzażem, z wygiętą w trąbę blachą i wysadzonem gdzieś na kanty zielonem okiem"22.

Głosy te Konrad Winkler skomentował następująco:

Osobnej wzmianki godne są bez watpienia wielopłaszczyznowe obrazy Czyżewskiego. Zaskoczona niemi swego czasu krytyka zachowała się wówczas w podobny sposób, jak nasi poczciwi kmiotkowie ongiś wobec ujrzanej po raz pierwszy lokomotywy. Cóż dopiero przeciętny ,znawca”, ten dostawał najczęściej paroksyzmu wściekłości. I nie bez kozery! Z punktu widzenia bowiem tradycyjnej estetyki wydają się te wielopłaszczyznowe eksperymenty czemś wprost niesłychanem. Lecz to, co przeciętnego widza oburza [...], powinna krytyka wyjaśnić [...]. Swoją drogą krytyka może się mylić [...] lecz zają́ się eksponatem powinna uczciwie, bez uprzedzeń i osobistych porachunków, a jedynie pod kątem widzenia sztuki, dawnej czy nowej ${ }^{23}$.

Także Leon Chwistek we wspomnianej publikacji Tytus Cayżenski a kryzys formizmu, zaczynającej się od słynnego zdania: „Stowarzyszenie formistów przestało istnieć" ${ }^{24}$, pisząc o przyszłości sztuki, podkreślał, że została ona wyznaczona właśnie przez prace Czyżewskiego, takie jak między innymi Zbójnik, Madonna oraz obrazy wielopłaszczyznowe.

Po latach opinie te skomentował również sam Czyżewski: „Wówczas na wystawie irytowały wszelkich kołtunów moje »obrazy wielopłaszczyznowe«. Skonstruowane z drzewa i kartonów były polichromowane. Chciałem w nich wyrazić w kilku płaszczyznach i przestrzeniach maximum plastyczności kolorowej formy"25.

21 T. S. [Sinko], Z Pałacu Sztuki. Wystawa formistów, „Czas”, 1921, nr 21, s. 3.

22 W., Z krakowskich wystaw sžtuki. Wystawa formistóm. - Z salonu Tow. Sztuk Pięknych. - Salon Wojciechowskiego, „Nowa Reforma”, 1921, nr 36, s. 1.

23 K. Winkler, Formiżm na tle wspótczesnych kierunkón w sæ̨uce, Kraków 1921, s. $80-81$.

24 L. Chwistek, Tytus Cayżewski a keryzys, s. nlb. 3.

25 T. Czyżewski, Mój formižm, „Głos Plastyków”, 1938, R. 5, nr 8-12, s. 13. 
Echa tych negatywnych ocen można jeszcze odnaleźć we wspomnieniach aktorki Zofii Ordyńskiej (1882-1972), biorącej udział w wieczorach futurystycznych, opisującej pierwszą wystawę grupy następująco:

W dzień otwarcia wystawy przewalały się przez Pałac takie tłumy krakowian, że trudno było się docisnąć do poszczególnych obrazów. Jedni w świętym oburzeniu załamywali ręce i ronili łzy nad upadkiem sztuki, inni bawili się znakomicie [...]. Największym powodzeniem cieszył się mały obrazek, mniej więcej $50 \mathrm{na} 60 \mathrm{~cm}$, oprawiony w masywną ramę, tworząca rodzaj pudła, na dnie którego można było podziwiać kawałek zardzewiałej spiralki, część maszynki do mielenia kawy i kilka innych metalowych odłamków, wygrzebanych ze śmietnika ${ }^{26}$.

Czyżewski pracował nad oryginalną koncepcją obrazów wielopłaszczyznowych co najmniej od 1915 roku, czyli już po swoim powrocie z Paryża - do stolicy Francji najpierw wyjechał w 1907 roku na dwa lata oraz powtórnie w 1910 roku. Po przyjeździe do kraju w 1912 roku artysta przedstawił swoje prace na wystawie, która po tygodniu zamknięto z powodu dużej kontrowersyjności obrazów: „gdy wróciłem do Polski po dwuletnim pobycie w Paryżu (1910-1912), ofiarowano mi »salę« w Krakowskim Pałacu Sztuki na Szczepańskim Placu, ale po tygodniu ówczesny prezes zorientował się, że moje obrazy to jednak nie to, co można by pokazać w Krakowie t. z. »średniej inteligencji«, i kazał wystawę zamknąć, a mnie zabronił wstępu do świątyni Apollona, gdzie kapłani byli staruszkowie z czasów Matejki" ${ }^{27}$. Niestety, poza tą relacją Czyżewskiego o samych pracach nic więcej nie wiadomo. Można jedynie przypuszczać,

26 Z. Ordyńska, To już prawie sto lat. Pamietnik aktorki, Wrocław-Warszawa-Kraków 1970, s. 171-172. Zofii Ordyńskiej Czyżewski zadedykował wiersz Mugy/ka z. okna, pochodzący z tomiku Zielone oko. Poezje formistyczne. Elektryczne wizje, Kraków 1920, oraz namalował portret wymieniany w: Katalog Formiści. Wystawa IV, Kraków, styczeń-luty 1921, poz. 23; Katalog Formiści. Wystawa X, Warszawa, kwiecień-maj 1921, poz. 10: Portret artystki dram. P. Zofii Ordyńskiej.

27 T. Czyżewski, Mój formižm, s. 12; J. Pollakówna, Tytus Czyżenski - Formista, s. 252; eadem, Cayżewski Tytus, [w:] Stownik artystów polskich, t. 1, Wrocław-Warszawa-Kraków-Gdańsk 1971, s. 414. 
że stanowiły one wyraz fascynacji nowymi nurtami w sztuce, z którymi artysta miał bezpośredni kontakt w Paryżu.

W tym też czasie powstały pierwsze prace, znane głównie z reprodukcji, wyznaczające kierunek poszukiwań, prowadzący w efekcie do obrazów wielopłaszczyznowych. Jednym z nich jest Madonna (1911) ${ }^{28}$ (il. 1), której stylistyka może kojarzyć się z pracami kubistów. Podobnie jak oni, Czyżewski rozpoczął w tym rysunku poszukiwania nowej koncepcji oddania przestrzeni pozwalającej na nowatorskie ujęcie bryły na płaszczyźnie. Zabiegiem najbardziej rzucającym się w oczy było rozbicie figur Madonny i Dzieciątka oraz ponowne ich połączenie. Wskutek tego zostały one zbudowane z jakby połamanych elementów o wyraźnie zaznaczonych krawędziach, dodatkowo podkreślonych gęstym układem kresek przypominających szrafowanie i wywołujących wrażenie zacienienia. Jednak mimo tego rozczłonkowania i przesunięcia poszczególnych komponentów, czytelność układu została zachowana. Centrum kompozycji zajmuje twarz Madonny, ukazana jednocześnie en face i z profilu, co sugeruje zacieniony fragment, odcięty od reszty zdecydowana, niemal pionową kreska. Madonna spogląda na Dzieciątko, widoczne w lewym dolnym narożniku. Między ich głowami przenikają się różnorodne formy, wśród których można odnaleźć przemieszane kawałki torsu, piersi i innych części ciała. W większości przeważaja płaszczyzny o ostrych krawędziach - kontrastuje z nimi górna część układu, zamknięta łukami, zakończonymi spirala. Omawiając tę pracę, nie sposób pominać zauważalnego w niej wpływu sztuki prymitywnej, na co wskazała Joanna Pollakówna, podkreślająca, że charakteryzuje ja „,naiwna melancholijność ludowego świątka”29, decydująca o niepowtarzalności rysunku. Porównując Madonne z rysunkiem noszącym tytuł Głowa (1915) (il. 2), można stwierdzić, że stanowił on kolejny etap poszukiwań artysty. Ponownie naszą uwagę przykuwa pociagły fragment twarzy z wyraźnie widocznym jednym okiem, zarysem ust i nosa, który w tym przypadku sugeruje ujęcie $3 / 4$. Jednak brakuje w nim drugiego

28 Rok 1911 jako data powstania rysunku Madonna widnieje w podpisie pod pracą reprodukowaną w publikacji L. Chwistka, Tytus Czyyżewski a kryzys. W późniejszych pracach data ta została przesunięta na rok 1913; zob. Formisici, poz. 156, s. 44.

29 J. Pollakówna, Tytus Cayżenski - Formista, s. 251.

30 Formiści, poz. 157, s. 44. 
oka. Można je zobaczyć nieco wyżej, w miejscu zajmowanym w poprzedniej pracy przez rodzaj chusty osłaniającej włosy Madonny, układającej się w charakterystyczny szpic na czubku głowy. Co ciekawe, forma ta została zastosowana ponownie, z tym że jej jednolitość zastapiono przecinającymi się i nachodzącymi na siebie płaszczyznami, wśród których odnajdujemy profil twarzy, oko i ucho. Zaproponowana koncepcja zbliża analizowane rysunki do fazy kubizmu analitycznego, jednak trudno je porównywać z czołowymi pracami Picassa i Braque'a z tego okresu. W przypadku Czyżewskiego należy raczej mówić o pewnej stylizacji na kubizm analityczny, o próbie rozbicia formy i o jednoczesnym ukazaniu jej kilku widoków, ale bez przekroczenia granicy czytelności. W tym samym duchu jest utrzymany Autoportret formistyczny z 1916 roku $^{31}$ (il. 3), umieszczony na okładce tomiku wierszy Czyżewskiego Zielone oko. Poezje formistyczne. Elektryczne wirjje (Kraków 1920) oraz na okładce zeszytu czasopisma „Formiści” z 1921 roku. Z typowym wizerunkiem rysunek ma niewiele wspólnego, gdyż trudno w nim odnaleźć jakiekolwiek podobieństwo do tego sposobu przedstawienia. Jest bardziej wariacją na temat samego autora. Jego twarz została uproszczona i zdeformowana. Równocześnie możemy odczytać ja en face i z profilu. Jednak nad pierwiastkiem kubizującym przeważa ekspresjonistyczny, ujawniający się w ostrej, chwilami zygzakowatej linii konturu, określającej kształt głowy i rysów twarzy. Dynamicznie jest także potraktowana partia tła, wypełniona przenikającymi się płaszczyznami, wyznaczonymi zdecydowanymi liniami o przewadze kierunków diagonalnych. Poza formą rysunku na uwage zasługuje również jego warstwa treściowa. Możliwe, że symbolizuje ona dwoistą naturę twórcy, co dodatkowo podkreśla podział tła na dwie przeciwstawne części zdominowane przez księżyc i słońce. Artyście towarzyszy zagadkowa postać o groteskowej twarzy, usytuowana przy dolnej krawędzi pracy ${ }^{32}$. Kompozycja ma kształt sześcioboczny, który został też wykorzystany w obrazie wielopłaszczyznowym

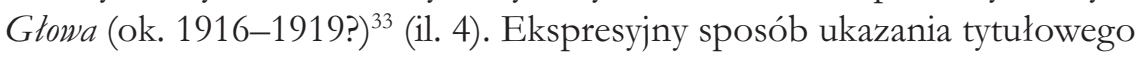
motywu powtarza schemat znany z rysunku, z tą różnica, że ostre linie

31 Ibidem, poz. 165, s. 44.

32 Interesująca analizę Autoportretu formistycznego przedstawiła Agata Soczyńska w książce Tytus Czyżewski. Malarz-poeta, Warszawa 2006, s. 59-61.

33 Formiści, poz. 164, s. 44. 
zastąpiły krawędzie tworzące całą siatkę „zgięć” pokrywających płaszczyznę obrazu, mających sugerować jego wielowymiarowość. Deformacji nie ulegają jedynie oczy, usta, prawe ucho i fragment okalających je włosów, które zarazem porządkują cały układ, jednocześnie decydując o jego czytelności. Ważną rolę odgrywa także głęboka rama, dodatkowo stwarzająca iluzję strukturalności przedstawienia złożonego z przenikających się brył, w rzeczywistości namalowanego na kawałku kartonu lub płótna. Podobna rama zamyka kolejny obraz wielopłaszczyznowy - Krajobraz ze stońcem $^{34}$ (il. 7), którego kształt przypomina trapez, rozszerzający się ku lewej stronie, stąd jego boki mają układ równoległy. Poza oryginalnym kształtem praca ta odznacza się dynamiczną kompozycją pejzażu zbudowanego z nachodzących na siebie, schematycznie potraktowanych szczytów górskich, dominujących nad niewielkim domkiem i przewyższającym go drzewem. Z ostrymi formami kontrastuja półkoliste pagórki oraz ogromna tarcza słoneczna, wypełniająca prawy górny narożnik. Motyw ten podkreślają skośne linie kompozycji, będące - zdaniem Joanny Pollakówny - ,„udosłownieniem « perspektywy w obrazie" ${ }^{35}$. Decydując się na taki zabieg, artysta prowadzi swoista grę z odbiorca, łącząc perspektywę zbieżna z kulisowa, łamiąc po raz kolejny tradycyjne zasady.

Do grupy obrazów wielopłaszczyznowych należy także Portret (Gto$w a)^{36}$ (il. 5), jednak w porównaniu z opisywaną wcześniej pracą o analogicznym tytule jej koncepcja różni się nieco. Ukazany przez artystę wizerunek jest zamknięty w wielobocznej nieregularnej bryle, wykreowanej na płaszczyźnie. Pomimo asymetrii można wydzielić w jej budowie dwie strefy: część dolna, oparta na stosunkowo regularnym wieloboku, oraz nałożoną na niego drugą formę o skomplikowanym układzie, której krawędzie zbiegają się w prawym górnym narożniku całej kompozycji. Poszczególne płaszczyzny - niby-ściany tej skomplikowanej struktury - przedstawiaja wycinki tytułowego motywu. Na trzech bokach z dolej strefy zostały namalowane dwa fragmenty twarzy ujętej en face oraz jej profil. Natomiast w górnej części są widoczne kawałki czoła i włosów. Wszystkie te elementy tworza iluzję wielopłaszczyznowej struktury, zastosowanej również

34 Ibidem, poz. 163, s. 44.

35 J. Pollakówna, Tytus Cayżenski - Formista, s. 261.

36 Formiści, poz. 166, s. 44. 
w kolejnej pracy - Salome. Obraz wielopłaszcsyznowy ${ }^{37}$ (il. 6). Na największej jego ściance jest ukazana cała postać Salome w długiej sukni, na następnych zaś można zobaczyć jej nagi tułów oraz zbliżenie twarzy, z która jest skontrastowany drugi, nieco zagadkowy wizerunek lub maska spinająca całość kompozycji. Przez ten swoisty symultanizm, odbiegający od prac futurystów zwykle wykorzystujących zasadę multiplikacji form w celu oddania faz ruchu, artysta rozbił główny temat, stosując oddalenia i przybliżenia wprowadzające dynamizm do przedstawienia. Podejmując temat Salome, oczarowującej swym tańcem Heroda, żądającej w zamian ściętej głowy Jana Chrzciciela, Czyżewski odwołał się do motywu bardzo popularnego na przełomie wieków. Tyle że już wtedy Salome nie była bohaterką z Nowego Testamentu, ale raczej uosobieniem postaci tragicznej, która według Oscara Wilde’a symbolizowała nieodwzajemnione uczucie, spełniające się dopiero w perwersyjnym pocałunku ściętej głowy proroka ${ }^{38}$. Ta wizja znalazła odzwierciedlenie również w Hymnach Jana Kasprowicza. Możliwe, że Czyżewski w swoim dziele starał się nawiązać do zmysłowego tańca Salome, sugerowanego przez dynamiczną strukturę pracy oraz różne ujęcia kobiecej sylwetki, mogące także łączyć się z koncepcją przemiany osobowości Salome bądź też samego artysty ${ }^{39}$. Jednak wydaje się, że zamiast warstwy treściowej ważniejsza była forma obrazu, co potwierdza komentarz samego autora:

Malarz, skonstruowawszy kilka płaszczyzn niemiarowych, złączonych ze soba, dał kompozycyjny stosunek linij (rysunku) przecinających te płaszczyzny i zarazem stosunek płaszczyzn do siebie. Wrażenie to kompozycyjne powinno polegać również na architektonicznej budowie płaszczyzn, ich wiązaniu i wiązanych ze sobą linii. Jest to rozbicie pospolitego rytmu obrazów jednopłaszczyznowych i umiarowych (obrazy bywają zwykle kwadratami lub prostokątami, stąd brak silnego rytmu - i monotonia), a zastapienie kompozycja i stosunkiem niemiarowych płaszczyzn, które są niejako »architekto-

37 Ibidem, poz. 160.

38 J. Białostocki, Judyta: ₹naczenie obrazu Giorgiona w historii tematu, [w:] idem, Symbole i obrasy w smiecie sztuki, Warszawa 1982, s. 133-135; P. Wittlich, Secesja. Sz̨tuka $i$ zycie, Warszawa 1987, s. 146.

39 A. Soczyńska, op. cit., s. 66-69. 
nicznym« rytmem dla wypełniających je linij (malowanych lub rysowanych). Malarz, komponując ton obrazu - chciał również dowieść bogactwa i możliwości stosowania linij i płaszczyzn - których użycie i łączenie się może być najrozmaitsze i dającą najrozmaitsze rytmy kompozycji i najrozmaitsze budowy - połączone ściśle z malowanymi liniami i płaszczyznami - obrazami. Dowód, że krajanie (rysowanie, malowanie) jakiejś płaszczyzny (obrazu) musi być do całości tejże płaszczyzny i zamiaru kompozycyjnego ściśle dostosowane, gdyż linie, płaszczyzny i barwy mają swe ścisłe teorie, jak tony muzyczne ${ }^{40}$.

Analizując ten tekst, nietrudno zauważyć, że Czyżewski dążył do zastapienia obrazów „umiarowych” typowych kwadratów lub prostokątów obrazami „nieumiarowymi”, zbudowanymi z kilku płaszczyzn. Miejsca ich połączeń miały być podkreślone liniami, tworzącymi rytm zastępujacy monotonię dotychczasowych przedstawień. Poza kompozycją artysta zwrócił uwagę na problematykę koloru, akcentując wielość kombinacji barwnych występujących między liniami i płaszczyznami budującymi poszczególne części obrazów wielopłaszczyznowych, podporząakowanych kompozycji całej pracy. Pogląd ten nawiązywał do teorii Wassilego Kandinskiego definiującego zależność kompozycji czysto malarskiej w odniesieniu do formy jako: „1. Kompozycję obrazu jako całości. 2. Stworzenie pojedynczych elementów formalnych, które wchodząc we wzajemne rozliczne kombinacje, składałyby się na kompozycję całości”" ${ }^{\prime 1}$. Także stwierdzenie Czyżewskiego, że „linie, płaszczyzny i barwy mają swe ścisłe teorie, jak tony muzyki" "42, bezpośrednio łączy się z teorią Rosjanina, zwracającego uwagę na „głębokie powinowactwa łączące rozmaite sztuki, a muzykę i malarstwo w szczególności” ${ }^{\prime 3}$.

Opracowana przez Czyżewskiego koncepcja wielopłaszczyznowości, dotąd przedstawiana jedynie na płótnie lub papierze, została rozwinięta w kolejnych dwóch dziełach, które dosłownie wyszły poza płaszczyznę obrazu.

40 T. Czyżewski, „Salome”, s. 14, fot. s. 19.

41 W. Kandyński, O duchowości w sztuce, Łódź 1996, s. 65.

42 T. Czyżewski, „Salome”.

43 W. Kandyński, op. cit., s. 64. Zob. też J. Gage, Kolor i kultura. Teoria i znaczenie koloru od antyku do abstrakcij, Kraków 2008, s. 236-241. 
Pierwsze z nich - Komposycja form. (Obraz wieloptaszcryznowy) (1918?) $)^{44}$ (il. 8) - jest zamknięte w pięcioboku wyznaczonym przez głęboką ramę, znana już z innych prac. Forma ta odzwierciedla kształt płaszczyzny, rodzaj tła, do którego zostały doczepione pozostałe elementy kompozycji. W prawym dolnym narożniku jest umieszczona niewielka półeczka o ściętych narożnikach, wystająca poza ramę. $\mathrm{Na}$ niej usytuowano kwadratowy obrazek przedstawiający twarz z linearnie zaznaczonymi rysami. Nad nim góruje prostokąt $z$ kontrastowo zestawionymi jasnymi i ciemnymi pionowymi pasami. Mniej więcej w jego połowie, z lewej strony, jest widoczna kolejna półka, na którą nałożono spiralną formę. Jej kształt podkreśla dodatkowo faliście wygięta płaszczyzna, rodzaj podpórki dołączonej od spodu. Do niej zaś nawiązuje rysunek spirali, umiejscowiony przy dolnej krawędzi pracy, pomiędzy układem zygzaków, a także następne rysunki znajdujące się w górnej części kompozycji. Podobny schemat można odnaleźć w obrazie Kompozycja form II. (Obraz, wieloplaszcryzznowy) (ok. 1920) ${ }^{45}$ (il. 9). Jego postać została sprowadzona do stojącego prostokąta, ponownie ograniczonego głębokimi ramami - boczne ramy mają falistą krawędź. Wnętrze obrazu porządkuje, przechodząca prawie przez cała jego długość, pionowa ścianka, do której jest dołączona spiralna ażurowa forma. Jej kształt powtarzaja malowidła wypełniające lewą stronę tła. Natomiast w dolnej części prawej strony pracy jest umieszczona deseczka, na niej ustawiono prostokątny obrazek, przedstawiający schematyczny portret osoby w ujęciu popiersiowym, zza którego wyłania się kolejny wizerunek. Wyżej zaś widać wygiętą faliście półkę, dochodzącą do lewego górnego narożnika pracy.

Obie kompozycje zostały zbudowane w podobny sposób. Ich koncepcja opiera się na połączeniu elementów trójwymiarowych z dwuwymiarowymi. Do tych ostatnich należa głównie przedstawienia postaci, oddane schematycznie na płaszczyźnie, tworzące przez to wrażenie obrazu w obrazie. Natomiast wrażenie spójności układu podkreślają części oparte na linii falistej i skręconej spiralnie, dekorujące tło, jak i dominujące w układzie przestrzennym. Wspomniane motywy charakterystycznie zwiniętych liści lub łodyg pojawiły się w tym samym czasie także w innych dziełach Czyżewskiego, np. Martwa natura z. motylami (Kwiaty i motyle,

44 Formiści, poz. 169, s. 45.

45 Ibidem, poz. 180. 
ok. 1920) ${ }^{46}$ i Kwiaty $(1920)^{47}$. Obie prezentują fantastyczna wizję ogrodu, otoczona rodzajem ramy lub zasłony, budującej dekoracyjna kulisę, za którą są widoczne motyle i stylizowane rośliny, ukazane w różnych ujęciach perspektywicznych.

Obrazy wielopłaszczyznowe Czyżewskiego nie miały analogii w sztuce polskiej, natomiast bardzo dobrze wpisywały się w poszukiwania artystyczne, przekraczające tradycyjne pojmowanie malarstwa i rzeźby, charakterystyczne dla innych twórców awangardowych.

Elizabeth Clegg w swojej książce poświęconej sztuce ostatnich trzech dekad istnienia Cesarstwa Austro-Węgierskiego porównuje obrazy wielopłaszczyznowe ze skulptomalarstwem (sculpto-peintures) Alexandre'a Archipenki ${ }^{48}$. Wychodząc z estetyki kubizmu, Archipenko zaczął wprowadzać do swoich dzieł gotowe przedmioty lub ich fragmenty wykonane z różnych tworzyw. Jedną z wcześniejszych zachowanych prac powstałych w tej technice jest Kobieta ₹ wachlarzem (1914, wł. Tel Awiw Museum of Art), ukazująca silnie uproszczona i zgeometryzowaną tytułowa postać namalowaną na płótnie, do którego doklejono drewnianą półeczkę, metalowy lejek, arkusz blachy i szklane buteleczki ${ }^{49}$. Ich zastosowanie spowodowało połązenie iluzjonistycznych form budowanych kolorem i światłocieniem z rzeczywistymi, wprowadzającym trzeci wymiar. Podobna idea wyjścia poza tradycyjne malarstwo przyświecała kubistom posługującym się od około 1912 roku kolażem, stanowiącym początek dalszych poszukiwań, których efektem była praca Gitara i butelka Bass Picassa (1914, wł. prywatna), pozbawiona tradycyjnej ramy, kojarząca się z rzeźbiarskim reliefem, wykonanym z kawałków drewna i innych materiałów. Te trójwymiarowe konstrukcje wpłynęły na Władimira Tatlina, tworzącego przestrzenne „reliefy” i „kontrreliefy”, zrywające wszelkie związki z malarstwem. Także w środowisku dadaistów połączenie rzeźby i malarstwa stało się istotnym problemem. Zjawisko to dobrze ilustruje

46 Ibidem, poz. 147, s. 44.

47 Ibidem, poz. 183, s. 45.

48 E. Clegg, Art, Design \& Architecture in Central Europe 1890-1920, New Haven-London 2006, s. 211.

49 Praca reprodukowana na stronie http://www.tamuseum.com (dostęp: 15.04.2011). 
Owoc dlugich doświadczen (1919, wł. prywatna) Maxa Ernsta, będący rodzajem asamblażu. Do wykonania tej pracy artysta użył drewnianych elementów, pełniących wcześniej inne funkcje, które pomalował i przyczepił do podłoża. Kompozycja została zamknięta typową ramą, decydująca o spójności układu, dodatkowo wzmocnioną brązowo-zieloną kolorystyką dominującą w pozostałej części dzieła ${ }^{50}$.

W tym samym okresie przedmioty trójwymiarowe, często objets trouvés, do swoich asamblaży określanych mianem „obrazów merz” wprowadzal też Kurt Schwitters. W dziełach powstałych między 1919 a 1921 rokiem jest widoczna droga stopniowego uwalniania się od malarstwa, prowadząca choćby od Konstrukeji dla arystokratek (1919) i Obrazu merz 29A. Obraz z kotem (1920), akceptujących tradycyjną ramę, ku pracom przypominającym reliefy, np. Bez. tytutu (1921), wychodzących poza nią ${ }^{51}$. Swoja koncepcję tworzenia artysta opisywał w 1924 roku następująco: „użyję jakiegokolwiek materiału, [...] jeśli obraz tego wymaga. Zestawiając różne materiały, mam przewagę nad tradycyjnym malarstwem olejnym o tyle, że nie tylko zestawiam kolor z kolorem, kształt z kształtem itd., ale również jeden materiał z innym, np. drewno z lnianym płótnem"52.

Omawiając obrazy wielopłaszczyznowe w kontekście eksperymentów innych artystów, wyraźnie widać, że Czyżewski, odchodząc od tradycyjnie pojętego malarstwa, nie wyzwolił się z niego całkowicie. W bezpośredni sposób wskazuje na to choćby użycie samej nazwy „obraz”, co prawda poszerzonej o przymiotnik „wielopłaszczyznowy”, podkreślający wielowymiarowość obrazu, co sytuuje go na granicy malarstwa i rzeźby, podobnie jak wspomniane wcześniej skulptomalarstwo Archipenki. Uwaga ta odnosi się głównie do dwóch ostatnich prac: Kompozycja form. (Obraz, wieloplaszcryznowy) i Kompozycja form II. (Obraz, wieloplaszcayznowy). Forma tych układów została zamknięta głęboką ramą - jej wprowadzenie odwoływało się do obrazu. Określona przez nią przestrzeń wypełniono trójwymiarowymi elementami, wykonanymi od podstaw przez Czyżew-

50 D. Elger, Dadaizm, Köln 2005, s. 68-69.

51 J. Elderfield, Kurt Schwitters, London 1985, s. 55, 69.

52 K. Schwitters, Merz, „Der Ararat”, 1921, Nr. 2, s. 3-9, cyt. za: K. Orchard, Kurt Schwitters. Jego àycie $i$ dzieło, [w:] Kurt Schwitters, kat. wystawy, oprac. A. Saciuk-Gąsowska, Muzeum Sztuki w Łodzi, Łódź 2003, s. 22. 
skiego lub też stanowiącymi fragmenty gotowych przedmiotów - zostały one przytwierdzone do podłoża pokrytego dekoracją malarską. Jednak nie podporządkowano ich jednemu głównemu motywowi, tak jak w przypadku prac Archipenki, którego Akt kobiecy (1920), określony jako „rzeźbo obraz”, był reprodukowany w czasopiśmie „Formiści” w 1921 roku, co świadczyło o dużym zainteresowaniu jego koncepcjami.

Obrazy wielopłaszczyznowe Czyżewskiego, malowane najpierw na płótnie lub tekturze, a później konstruowane z różnych elementów, były najodważniejszym eksperymentem w ówczesnej sztuce polskiej. Stanowiły przykład modyfikacji tradycyjnej idei obrazu, a jednocześnie pokazywały potrzebę przekraczania granic między gatunkami, charakterystyczną dla twórców z kręgu awangardy.

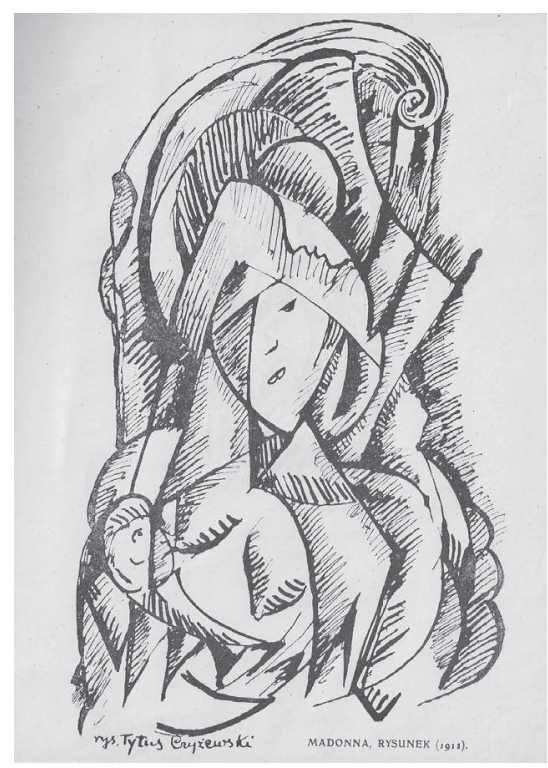

Il. 1. Tytus Czyżewski, Madonna, 1911 r., praca zaginiona, repr. L. Chwistek, Tytus Cayżenski a krysys formizmu, Kraków 1922

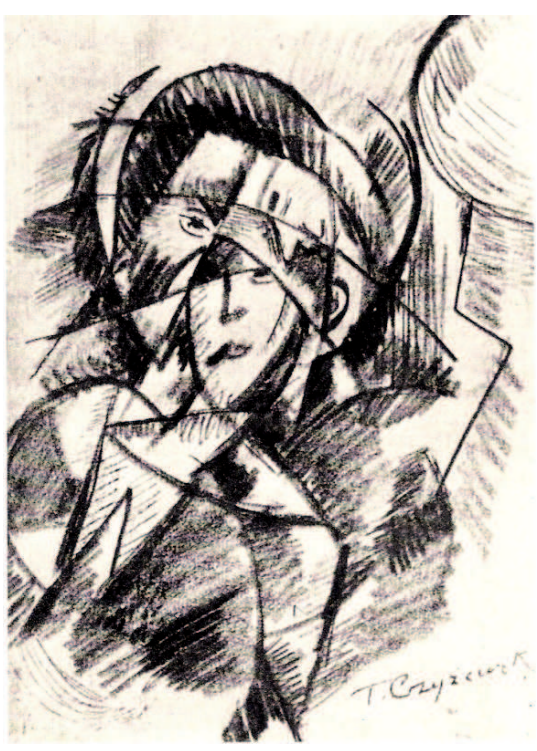

Il. 2. Tytus Czyżewski, Głowa, 1915 r., praca zaginiona, repr. „Głos Plastyków”, 1938, nr 8-12 
[562]

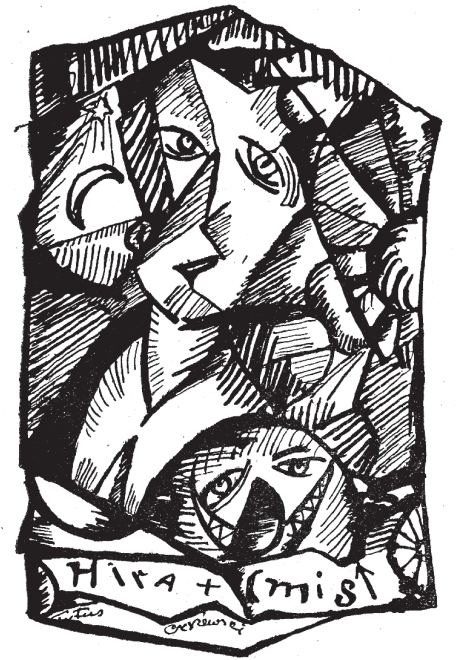

Il. 3. Tytus Czyżewski, Autoportret formistyczny, 1916 r., praca zaginiona, repr. „Formiści”, 1921, z. 4

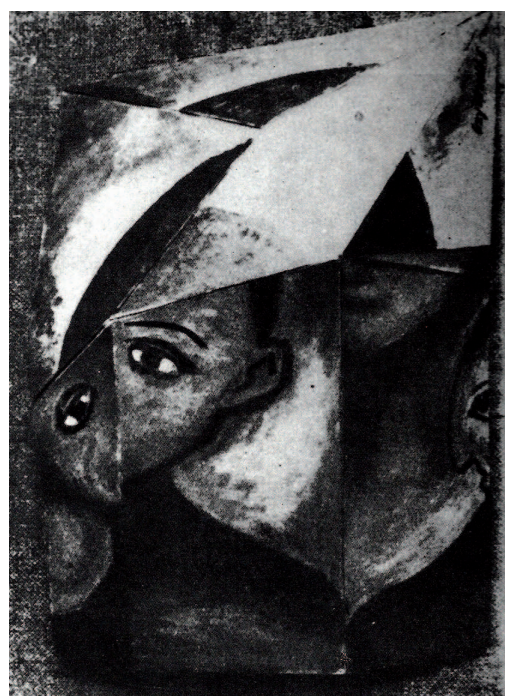

Il. 5. Tytus Czyżewski, Portret (Glowa). Obraz wielopłaszczyznowy, praca zaginiona, repr. „Nowości Ilustrowane”, 1917, nr 48

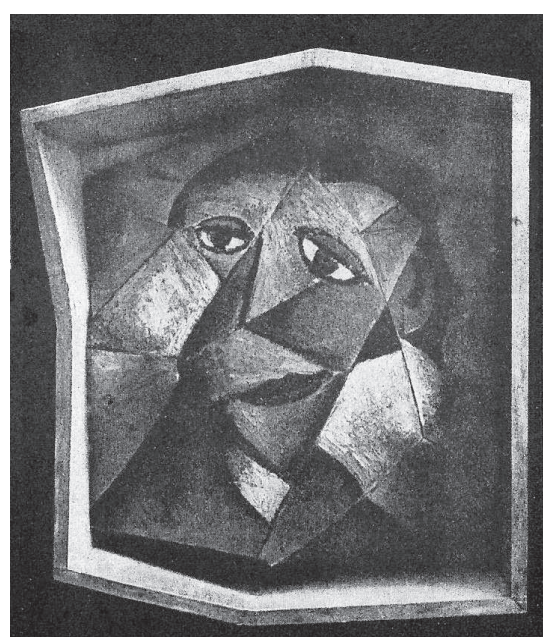

Il. 4. Tytus Czyżewski, Gtowa. Obraz wieloplaszcsyznowy, ok. 1916-1919 r., praca zaginiona, repr. L. Chwistek, Tytus Czyżenskei a kryzys formizmu

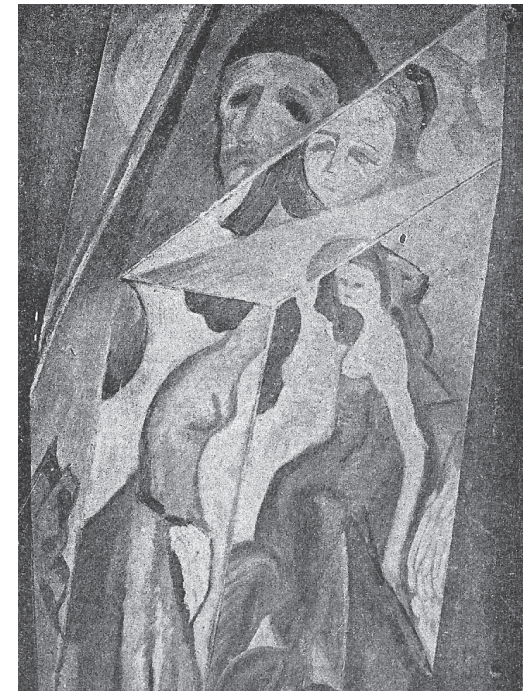

Il. 6. Tytus Czyżewski, Salome. Obraz, wieloplaszcayznowy, ok. 1915-1919 r., praca zaginiona, repr. „Wianki”, 1919, nr 1 


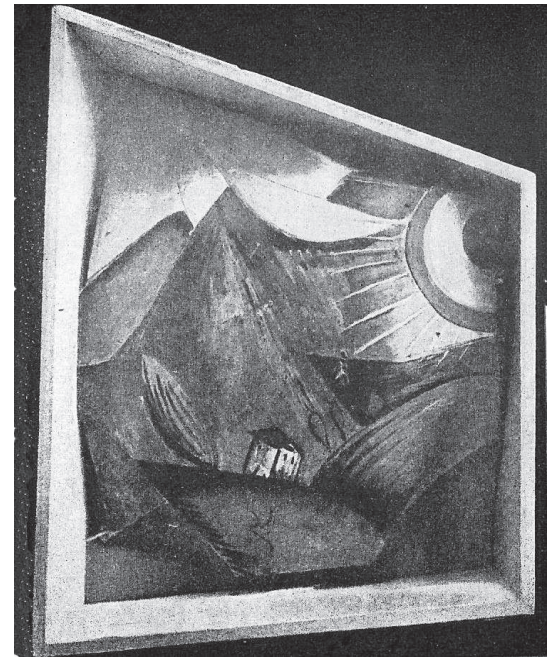

Il. 7. Tytus Czyżewski, Krajobraz ze stońcem. Obraz wieloplaszczyznowy, praca zaginiona, repr. L. Chwistek, Tytus Czyżenskei a kryzys formizmu

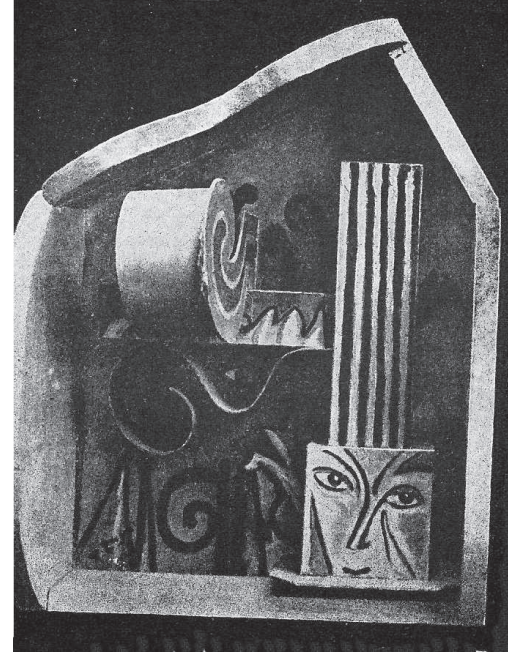

Il. 8. Tytus Czyżewski, Komposycja form. Obraz wieloplaszcryznowy, ok. 1918 r., praca zaginiona, repr. L. Chwistek, Tytus Cayżenski a kryzys formizmu

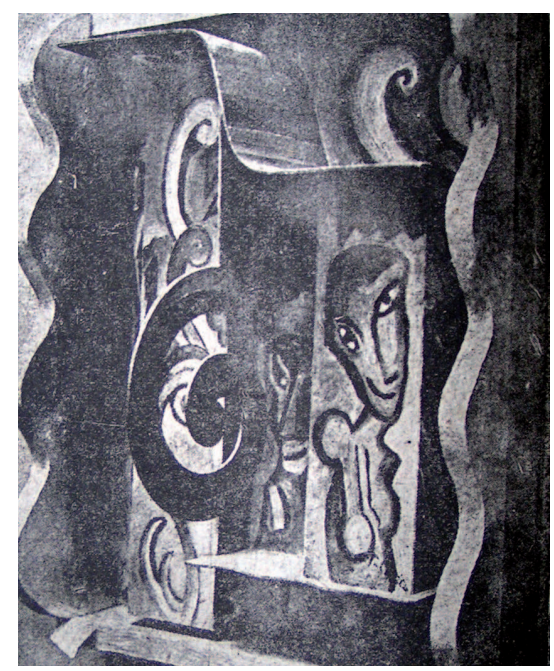

Il. 9. Tytus Czyżewski, Kompozycja form II. Obraz wieloplaszcayznowy, ok. 1920 r., praca zaginiona, repr. „Nowości Ilustrowane”, 1921, nr 12 


\section{Summary}

\section{Tytus Czyżewski’s multi-plane pictures}

Tytus Czyżewski created multi-plane pictures that became unique elements grown in the milieu of Formists, artistic group active between 1917 and 1922. Unfortunately, none of those pictures survived till today, and the sole documentation constitute six photographs of them.

Czyżewski started working on his multi-plane paintings as early as 1915, after he returned from Paris. At that time the first drawings were created; they demonstrated the path of the artist's searching that finally led him to multi-plane paintings. Among the works within this group were Madonna, Glowa [The head], and Autoportret formistyczny [Formist self-portrait], characterized by breaking the form and its reassignment with concurrent presentation of several views, which refered to the works created within the circle of Cubists. This mode of depiction was employed in the following works Portret (Glowa) [Portrait (head)] and Salome, characterized by inscribing the motif within a geometric figure depicted on a plane. The concept was discussed by the artist himself in a theoretic text Salome. (Obraz wieloplaszcryznowy) [Salome (multi-plane picture)] (1919), in which Czyżewski pointed to the need of replacing traditional paintings with pictures constructed with several planes. The points at which the planes were joined were to be further stressed with lines, thus creating a rhythm that replaced the humdrum of former pictures. Until then, the idea was carried out only on canvas and cardboard and was developed in later works that literally went beyond a single plane. In Kompozycja form II. (Obraz wieloplaszcryznowy) [The composition of forms (multi-plane picture)] the artist connected flat and spatial elements that on numerous occasions were fragments of objects.

Multi-plane pictures by Czyżewski, painted first on a plane and then constructed from various materials, were the boldest example of experimentation in Polish art. They demonstrated the need to exceed the traditional concept of painting, characteristic for avant-garde artists, e.g. Alexandre Archipenko and his sculpto-paintings. 